\title{
CATCHES OF THE SPORT FISHING COMPETITIONS ALONG THE ALGARVE COAST (PORTUGAL): SPECIES, SIZES, CATCH RATES, AND TRENDS
}

\author{
Ana I. GUERREIRO ${ }^{1 *}$, Pedro VEIGA ${ }^{1,2}$, and Karim ERZINI ${ }^{1,2}$ \\ ${ }^{1}$ Universidade do Algarve, F.C.T., Campus de Gambelas, 8005-139 Faro, Portugal \\ ${ }^{2}$ Centro de Ciências do Mar (CCMAR), Universidade do Algarve, Campus de Gambelas, \\ 8005-139 Faro, Portugal
}

Guerreiro A.I., Veiga P., Erzini K. 2011. Catches of the sport fishing competitions along the Algarve Coast (Portugal): species, sizes, catch rates, and trends. Acta Ichthyol. Piscat. 41 (3): 165-169.

\begin{abstract}
Background. Stocks of many marine fishes are in decline and a number of studies suggest that for some species the impact of recreational angling may be important. To date, only recreational (leisure) fishing surveys have been conducted in Portugal, with no studies on beach angling competitions, dynamically increasing in number over the past 10 to 20 years. In view of the above, we decided to evaluate the impact of such events on the Algarve coast (southern Portugal) in terms of the abundance, diversity, and respective weight of fish species caught and outline some conservation measures and recommendations for the management of the targeted species.

Materials and methods. Participants of 22 angling competitions taking place between February and June 2007 were surveyed. In each competition a random sample of anglers was interviewed, and the specimens caught by each participant were identified, weighed, and measured.

Results. Thirteen taxa belonging to eight families were identified, and the most common were: garfish, Belone belone (Linnaeus, 1761); mullets, Mugilidae (not identified); and mackerels, Scomber spp. A total of 563 specimens were sampled, totalling $75.4 \mathrm{~kg}$ of weight, with the average catch per angler weighing $0.5 \pm 0.05 S E(n=153) \mathrm{kg}$. Differences were also observed between the length at first maturity $\left(L_{50}\right)$ of the specimens caught and their respective Minimum Landing Size (MLS) and Allowed Minimum Size (AMS), most particularly in the case of the European seabass, Dicentrarchus labrax (L.), with almost all individuals caught measuring below the speciesspecific $L_{50}$. Analysis of time series of competition results (1996-2009) showed no evidence of a decrease in catches or in mean weight.

Conclusion. Based on the results we propose that the AMS for beach angling competitions should be increased to the MLS in order to prevent the capture of juvenile fishes, especially the sea bass. Future studies should address the size selectivity of the hooks used in beach competitions, with a view to the implementation of a minimum hook size for competitions.
\end{abstract}

Keywords: Algarve, saltwater fishing competitions, conservation, sport fishing, sport anglers

\section{INTRODUCTION}

The available information on numerous marine stocks indicates that they are in decline, and many recreational anglers claim that their catches are decreasing in size and number as a result (Smith and Pollard 1996, Richardson et al. 2006). Fishing activity of any type, commercial or recreational, may be harmful to fish (e.g., limiting their size, age range, density, and reproduction), the trophic webs and relationships and, indirectly, all the aquatic ecosystems (Post et al. 2002).

In Portugal, recreational (amateur) fishing can be divided into two types: leisure fishing and sport fishing. Leisure fishing is best described as a purely recreational hobby, while sport fishing is competition-oriented (Anonymous 2000). Competitions based on rod and reel methods are a relative- ly recent phenomenon in Portugal, formally recognised in 1947 by the foundation of the Portuguese Federation of Sport Fishing (FPPD). To date only recreational (leisure) fishing surveys have been conducted in Portugal (Rangel and Erzini 2007, Veiga et al. 2010).

The main objective of this study was to describe sport fishing catches in the south of Portugal and to evaluate trends in abundance, weight, mean size, and diversity of catches taken during sport fishing competitions. Specifically we tested the following hypotheses:

- There has been no decrease in mean catch per angler over the past 15 years;

- There has been no decrease in mean weight fish caught over the past 15 years.

The secondary objective was to outline potential con-

\footnotetext{
* Correspondence: Dr. Ana I. Guerreiro, Universidade do Algarve, F.C.T., Campus de Gambelas, 8005-139 Faro, Portugal, Phone: (00351) 965245791, e-mail: ana.albarraque@gmail.com
} 
servation measures and make recommendations for the management of the species affected.

\section{MATERIALS AND METHODS}

The Algarve region is located between parallels $37^{\circ} 35^{\prime}$ and $36^{\circ} 58^{\prime} \mathrm{N}$, across the meridians $7^{\circ} 25^{\prime}$ and $9^{\circ} 00^{\prime} \mathrm{W}$ (Anonymous 1986). Monitoring of the 2007 Sport Fishing Championships took place between February 24 and June 16 , and included a total of 22 competitions that lasted $4 \mathrm{~h}$ each (Anonymous 2007a)

Sampling surveys consisted of two stages: 1) contestants, chosen at random, were interviewed after the end of the competition, and 2) their catches analysed, with each fish identified to the lowest possible taxon, measured (TL, nearest $\mathrm{mm}$ ) and weighed (precision, $2 \mathrm{~g}$ ).

The total catch weight of the competition and the total number of individuals caught by each competition angler were used to calculate the average weight of fish caught per angler per hour $\left(\mathrm{CPUE}_{\mathrm{p}}\right)$ and the average number of fish per angler per hour $\left(\mathrm{CPUE}_{\mathrm{n}}\right)$.

Statistics for the Algarve competitions, covering the period from 1996 to 2009, were obtained from sport fishing associations. These data were used to analyse trends in catches and sizes and to test the above-mentioned hypotheses. Specifically, we evaluated trends in mean weight of the 10 largest fish caught, the mean catch for the top ten anglers per competition, the weight of the largest fish caught, and the mean total catch per competition.

\section{RESULTS AND DISCUSSION}

Monitoring of 22 sport fishing competitions lasting 4 hours each took place between February 24 and June 162007. In total, 563 fish belonging to 13 taxa were recorded during the surveys, between February and June 2007. The most important taxa, both in terms of abundance and weight, were: garfish, Belone belone (Linnaeus, 1761); mullets, Mugilidae (not identified); and mackerels Scomber spp. (Table 1). In comparison, Rangel and Erzini (2007), in the northern Portugal beach angling, identified sea bream Diplodus spp. and European seabass, Dicentrarchus labrax (L.), as the most important species caught by recreational anglers. More recently, Veiga et al. (2010) conducted a study on recreational fishing from the shore in the south of Portugal, which included our study area, and described white seabream, Diplodus sargus (L.), as the dominant species, accounting for $48 \%$ of the total catches by number and being caught all across the study area and year round.

The differences with the current study could be explained by different strategies adopted by the recreational (leisure) and sport anglers, considering target species. Probably sport anglers target the more abundant species in beaches such as mullets, garfish, and mackerel. In contrast, recreational anglers are probably more interested in sea breams and bass that have higher gastronomic value and are more abundant in the areas often chosen for this type of fishery, such as jetties or cliffs (where the rocky topography provides refuge for large individuals of European seabass and sea breams). In fact, Pradervand and Govender (2003) found the same dichotomy in catches between recreational and sport anglers, with the latter group being generally more selective.

In this study, all the European seabass caught were below the minimum landing size of $36 \mathrm{~cm}$ TL (Fig. 1). This represents a high volume of illegal specimens caught, explained by the current discrepancy between the allowed minimum size (AMS) for competitive sport angling and the minimum landing size for commercial and recreational fishing. $69 \%$ of the spotted sea bass, Dicentrarchus punctatus, (L.) and $4 \%$ of the mullets (Mugilidae) were also below the MLS.

In this study, the average catch rates, in number and weight, of sport fishermen in competitions were 0.91 fish per angler per hour and $0.12 \mathrm{~kg}$ per angler per hour. In the south and south-west coast of Portugal, Veiga et al. (2010) recorded 1.11 fish per angler per hour and $0.21 \mathrm{~kg}$

Species recorded in the beach angling competitions analysed (Algarve, southern Portugal,

Table 1 with minimum landing sizes (percentage contribution is given in parentheses)

\begin{tabular}{llcccc}
\hline Family & Scientific name & $\begin{array}{c}\text { MLS } \\
{[\mathrm{TL}, \mathrm{cm}]^{*}}\end{array}$ & Number & Weight $[\mathrm{Kg}]$ & Conservation status \\
\hline Belonidae & Belone belone & none & $236(42.0)$ & $24.8(32.7)$ & $\mathrm{II}^{* * *}$ \\
Scombridae & Scomber spp. & 20 & $100(18.0)$ & $15.5(20.4)$ & $\mathrm{II}^{* * *}$ \\
Mugilidae & & 20 & $107(19.0)$ & $25.0(32.9)$ & $\mathrm{NA}^{* *}$ \\
Moronidae & Dicentrarchus labrax & 36 & $74(13.2)$ & $4.3(6.0)$ & $\mathrm{CT}^{* * *}$ \\
& Dicentrarchus punctatus & 20 & $13(2.2)$ & $2.4(3.1)$ & $\mathrm{II}^{* * *}$ \\
& Diplodus sargus & 15 & $12(2.0)$ & $1.6(2.1)$ & $\mathrm{CT}^{* * *}$ \\
Sparidae & Diplodus bellottii & 15 & $4(0.7)$ & $0.4(0.5)$ & $\mathrm{CT}^{* * *}$ \\
& Sparus aurata & 19 & $3(0.5)$ & $0.6(0.7)$ & $\mathrm{CT}^{* * *}$ \\
Soleidae & Spondyliosoma cantharus & 23 & $1(0.2)$ & $0.1(0.1)$ & $\mathrm{CT}^{* * *}$ \\
Carangidae & Pegusa lascaris & 24 & $3(0.5)$ & $0.2(0.2)$ & $\mathrm{CT}^{* * *}$ \\
Trachinidae & Trachinotus ovatus & none & $3(0.5)$ & $0.1(0.1)$ & $\mathrm{NA}^{* * *}$ \\
TOTAL & & none & $7(1.2)$ & $0.5(0.6)$ & $\mathrm{NA}^{* * *}$ \\
\hline
\end{tabular}

MLS = minimum landing size; $\mathrm{CT}=$ commercially threatened; $\mathrm{II}=$ incomplete information, NA = not assessed;

* Anonymous 2007b; ** Collares Pereira et al. 2000; *** Anonymous 2011. 
per angler per hour for recreational anglers, which were also higher than the corresponding values of 0.46 fish per angler per hour and $0.08 \mathrm{~kg}$ per angler per hour recorded by Rangel and Erzini (2007) for recreational anglers in the north of Portugal. The differences in catch rate value previously mentioned reflect a greater similarity between the recreational and the competition fishing in the South and Southwest of Portugal, which is higher compared with the values found by Rangel and Erzini (2007) for the north. Compared with this study, the difference might be due to the generally higher fishing success of anglers participating in competitions (Brouwer and Buxton 2002, Pradervand and Baird 2002), while in the study of Veiga et al. (2010) it might be related to the kind of habitat, beaches and cliffs, whereas in Rangel and Erzini (2007) only beaches were fished.

The mean number of beach angling competitions increased from 2 in 1996 to more than 40 in 2007 (Fig. 2). In the period from 1996 to 2000 , the mean catch remained fairly constant at approximately $0.9 \mathrm{~kg}$ per angler per competition, then increased to approximately $1.5 \mathrm{~kg}$ per angler per competition for the period from 2001 to 2006 (Fig. 3). However, the variability in some years was considerable. The largest fish caught during this period weighed $1.78 \mathrm{~kg}$, but no information on the species is available (Fig. 4).
These results suggest that we cannot reject the null hypotheses that there have been decreases in catches or in mean weight over the past 14 years (1996-2009) in sport fishing competitions taking place on the Algarve beaches. While this contradicts the opinions and beliefs of anglers interviewed both in the north and south of Portugal (Rangel and Erzini 2007, Veiga et al. 2010), an explanation can be found in the differences between recreational and sport angling. In the latter, the anglers in competitions focus on the more abundant pelagic fish (chub mackerel and garfish) and mullets, which have little or no commercial value, in order to maximise their catches, whereas recreational anglers target the more highly prized sea breams and European seabass that are also heavily fished by the commercial fishermen. Given that commercial fishing seems to have a far greater impact than sport angling, it is therefore to be expected that there are no decreasing trends in mean sizes or in catches in angling competitions where most of the catch consists of noncommercial species.

\section{CONCLUSION}

In conclusion, there is no evidence for declining catches or mean size of the main species caught by sport fishers in competitions in the south of Portugal. Of concern,
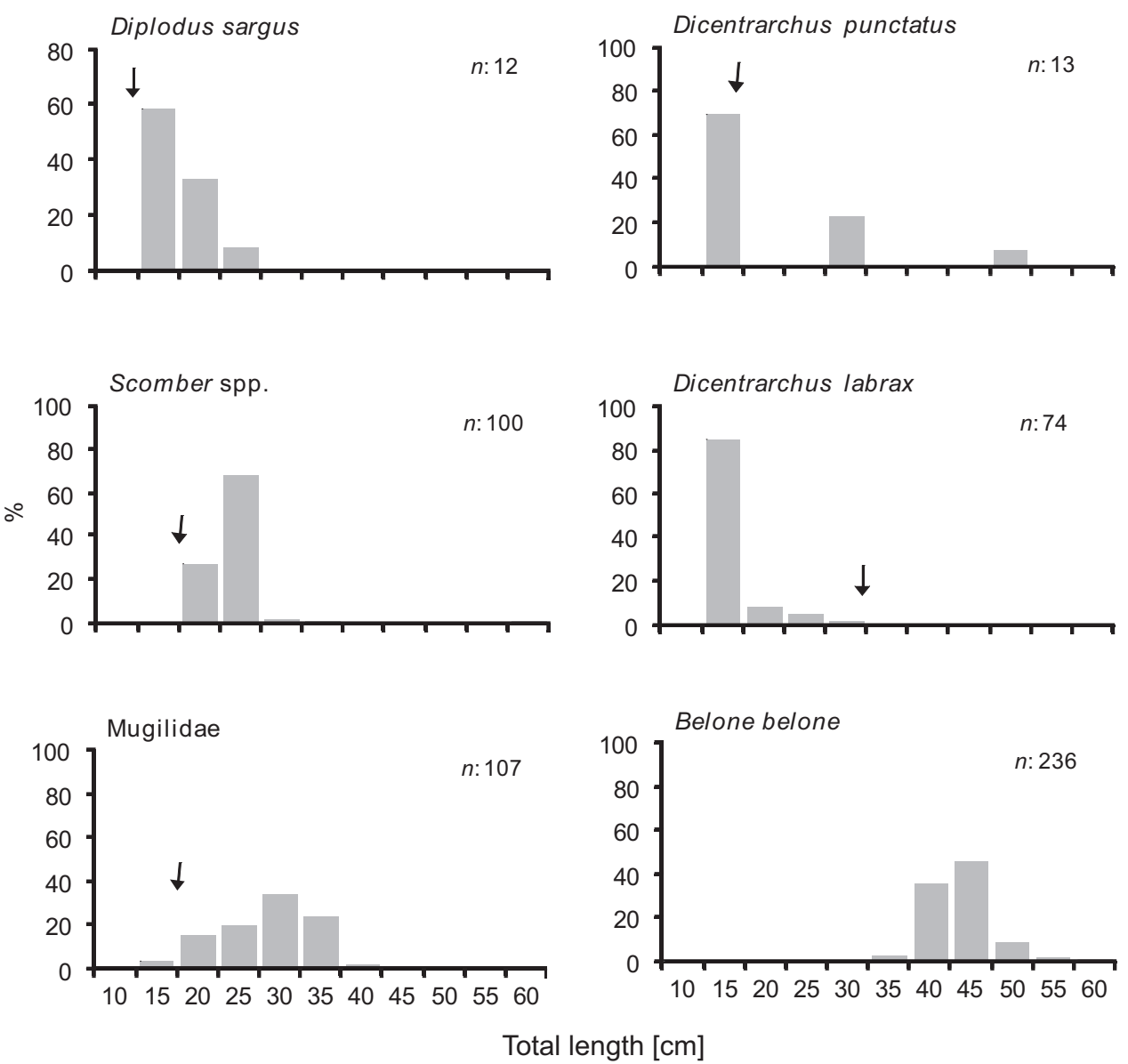

Fig. 1. Relative frequencies of the classes of length of Diplodus sargus, Dicentrarchus punctatus*, Scomber spp., Dicentrarchus labrax, Mugilidae, and Belone belone (f) caught during beach angling competitions (Algarve, southern Portugal); MLS $(\downarrow)=$ minimum landing size (Anonymous 2007b); *without studies related to $L_{50}$ 


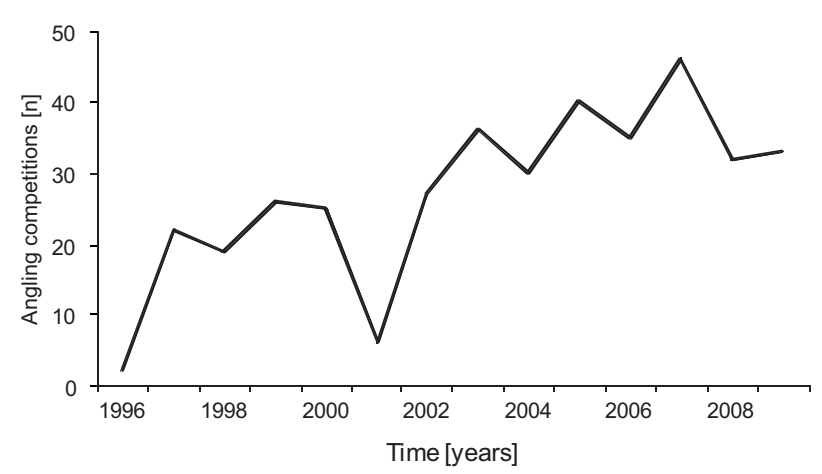

Fig. 2. Number of beach angling competitions (Algarve, southern Portugal; 1996-2009)

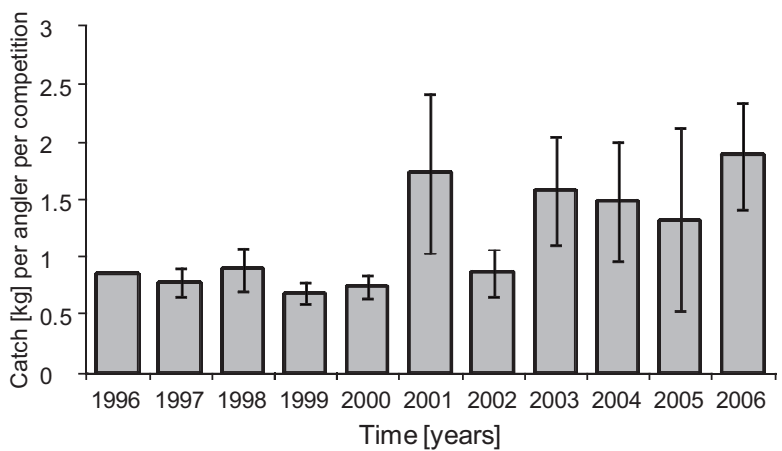

Fig. 3. Catch per angler per competition during angling competitions; Algarve, Portugal for the top 10 anglers in each competition (mean $\pm \mathrm{SE}$ ) $[\mathrm{kg}$ per angler per competition)

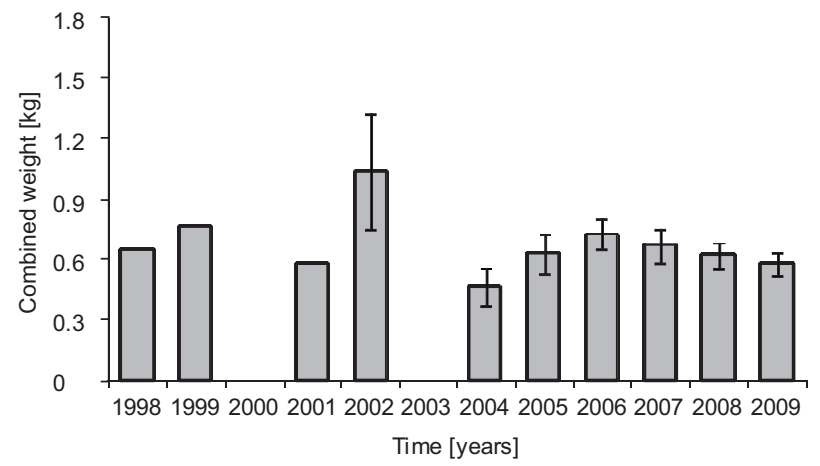

Fig. 4. The combined weight of ten largest fish caught per angling competition; Algarve, Portugal (mean $\pm \mathrm{SE}$ )

however, is the $15-\mathrm{cm}$ size limit allowed in competitions for European sea bass. This is far below the legal minimum landing size for commercial and recreational fisheries and far below the length at first maturity (NW Europe: males, 32-36 cm; females, $42 \mathrm{~cm}$; Pawson and Pickett 1996). Undersized sea breams (Sparidae) are also frequently caught and retained in competitions. We recommend that actual minimum legal sizes should be implemented in sport fishing competitions, rather than the current minimum sizes that allow undersized fish, particularly sea bass, to be retained. Competitions should also not take place in certain beaches and times of the year when juvenile sea bass are abundant.

\section{ACKNOWLEDGEMENTS}

Funding for this study was provided by POCI/MAR/58/57/2004 (SPORTFISH) project. We are grateful to all the people who assisted in the execution of this work.

\section{REFERENCES}

Anonymous 2000. Decreto-lei n²46/2000 de 29 de Setembro. Diário da República Electrónico http://www.dre.pt/ [In Portuguese.]

Anonymous 2007a. Calendário regional de 2007, competições de pesca desportiva [Regional calendar of 2007 sport fishing competitions.] Associação Regional de Pesca Desportiva do Algarve. [In Portuguese.]

Anonymous 2007b. Espécies sujeitas a tamanho ou peso mínimo de captura. [Species subject to minimum weight or size of catch.] Direcção Geral das Pescas e Aquicultura. [Fishing and Aquaculture General Direction.] http://www.picapeixe.web.pt/Portaria_27_de_2001.pdf_[In Portuguese.]

Brouwer S.L., Buxton C.D. 2002. Catch and effort of the shore and skiboat linefisheries along the South African Eastern Cape coast. South African Journal of Marine Science 24 (1): 341-354. DOI: $10.2989 / 025776102784528286$

Collares Pereira M.J., Cowx I.G., Ribeiro F., Rodrigues J.A., Rogado L. 2000. Threats imposed by water resource development schemes on the conservation of endangered fish species in the Guadiana River basin in Portugal. Fisheries Management and Ecology 7 (1-2): 167-178.

DOI: $10.1046 /$ j.1365-2400.2000.00202.x

Pawson M.G., Pickett G.D. 1996. The annual pattern of condition and maturity in bass (Dicentrarchus labrax L.) in waters around England and Wales. Journal of the Marine Biological Association of the United Kingdom 76 (1): 107-125. DOI: 10.1017/S0025315400029040

Anonymous 1986. Monografias hidrológicas dos principais cursos de água de Portugal Continental. [Hydrological monographs of the major water streams of mainland Portugal.] Direcção Geral dos Recursos e Aproveitamentos Hidráulicos. Ministério do Plano e da administração do Território, Secretaria de Estado do Ambiente e Recursos Naturais, Portugal. [Directorate General for Resources and Hydraulic Works, Ministry of Planning and Territorial Administration, Secretary of State for Environment and Natural Resources, Portugal.] [In Portuguese.]

Post J.R., Sullivan M., Cox S., Lester N.P., Walters C.J., Parkinson E.A., Paul A.J., Jackson L., Shuter B.J. 2002. Canada's recreational fishery: The invisible collapse? Fisheries 27 (2): 6-17.

DOI: $10.1577 / 1548-8446(2002) 027<0006$ : $\mathrm{CRF}>2.0 . \mathrm{CO} ; 2$

Pradervand P., Baird D. 2002. Assessment of the recreational line fishery in selected Eastern Cape estuaries: trends in catches and effort. African Journal of Marine Science 24 (1): 87-101. DOI: 10.2989/025776102784528592

Pradervand P., Govender R.D. 2003. Assessment of catches in shore angling competitions from the border region of the Eastern Cape, South Africa. African Zoology 38 (1): 1-14.

Rangel M.O., Erzini K. 2007. An assessment of catches and harvest of recreational shore angling in north of Portugal. 
Fisheries Management and Ecology 14 (5): 343-352.

DOI: $10.1111 / j .1365-2400.2007 .00560 . x$

Richardson E.A., Kaiser M.J., Edwards-Jones G., Ramsay K. 2006. Trends in sea anglers' catches of trophy fish in relation to stock size. Fisheries Research 82 (1-3): 253-262. DOI: 10.1016/J.FISHRES.2006.05.014

Smith A.K., Pollard D.A. 1996. The best available information-some case studies from NSW, Australia, of conservation-related management responses, which impact on recreational fishers. Marine Policy 20 (3): 261-267.

DOI: 10.1016/0308-597X(96)00011-5

Anonymous 2011. The IUCN Red List of Threatened species. Conservation status. www.iucnredlist.org
Veiga P., Ribeiro J., Gonçalves J.M.S., Erzini K. 2010. Quantifying recreational shore angling catch and harvest in the south of Portugal (north-east Atlantic Ocean): implications for conservation and integrated fisheries management. Journal of Fish Biology 76 (9): 2216-2237. DOI: 10.1111/j.1095-8649.2010.02665.x

Received: 13 July 2010

Accepted: 6 June 2011 Published electronically: 30 September 2011 